\title{
OFFENSIVE LANGUAGE AND SERIOUS HARM: APPLICATION OF THE FILMS, VIDEOS, AND PUBLICATIONS CLASSIFICATION ACT 1993
}

\author{
Kate Wilson*
}

\begin{abstract}
Section 3A of the Films, Videos, and Publications Classification Act 1993 allows age-restriction of a publication if it contains highly offensive language that is likely to cause serious harm. The Office of Film and Literature Classification and the Film and Literature Board of Review have failed to apply this section consistently. They have categorised the same word as both offensive and not offensive and the same harm as serious and not serious throughout their reports. They have also avoided substantive consideration of the New Zealand Bill of Rights Act 1990. An analysis of social science research provides a solid grounding on which the requirements of the section could be applied. Additionally, a more thorough analysis of the severity of harm could be reached through a comprehensive application of the New Zealand Bill of Rights Act 1990. Harm should be balanced against the merits of the publication and the importance of freedom of expression in order to determine whether it is serious enough to justify a restriction. This approach would lead to fewer restrictions under $\mathrm{S} 3 \mathrm{~A}$ and consistency throughout future decisions.
\end{abstract}

\section{INTRODUCTION}

In today's society we are surrounded by offensive language: in books and films, displayed on posters and in everyday conversations. It affects different people in different ways, with some members of society actively avoiding foul speech and others openly embracing it. The presence of offensive language in publications is undeniable. New Zealand's classification process allows for publications to be restricted for a number of reasons, including on the basis of offensive language. Since 2005, offensive language in a publication that is deemed to cause serious harm to young people can result in restriction of the publication on the basis of age, through s $3 \mathrm{~A}$ of the Films, Videos, and Publications Classification Act 1993 (FVPC Act). Enforcing the Act brings up a number of issues

* Submitted as part of the LLB(Hons) programme at Victoria University of Wellington. I am most grateful to my supervisor, Steven Price, for his inspiration and guidance. 
surrounding offensive language use and when it is acceptable to restrict it. This article aims to identify the issues that have arisen from an assessment of whether the restrictions are justified under s $3 \mathrm{~A}$, and make suggestions on how to improve application in the future, with emphasis on social science research and more thorough application of the New Zealand Bill of Rights Act 1990 (NZBORA).

This article first analyses the application of s 3A by both the Office of Film and Literature Classification (the Office) and the Film and Literature Board of Review (the Board) and identifies the irregularity with which the level of offensiveness and level of harm are identified in classification reports, as well as the inconsistency with which the NZBORA is applied. It then suggests a more thorough and balanced approach through consideration of social science research on what makes language more or less offensive, as well as possible harm that could result from the use of offensive language. Finally, it shows that a more comprehensive application of the NZBORA to s 3A will lead to a more consistent and thorough assessment of what harm is serious enough to justify a restriction of freedom of expression under the FVPC Act.

\section{THE FILMS, VIDEOS, AND PUBLICATIONS CLASSIFICATION ACT 1993}

Publications in New Zealand are classified under the FVPC Act. A publication can be any number of things from a can of energy drink to a campervan. ${ }^{1}$ Films generally require a label reflecting a rating of some form under the FVPC Act, with a number of exceptions. ${ }^{2}$ Books and any other publications are only classified upon request of certain persons, including the Chief Censor or any person with the leave of the Chief Censor. ${ }^{3}$ The FVPC Act sets up the Office whose role it is to classify any publication submitted to it. ${ }^{4}$ The Office can give a publication a classification of unrestricted, objectionable, or objectionable except under certain circumstances (including age restriction). ${ }^{5}$ A decision made by the Office can be reviewed by the Board, ${ }^{6}$ and matters of law can be appealed to the High Court and Court of Appeal. ${ }^{7}$

1 Films, Videos, and Publications Classification Act 1993, s 2 [FVPC Act]. See for example Office of Film and Literature Classification (OFLC) Miss Svenson's Classroom Detention (1101242, 7 June 2016); and OFLC Wicked Camper DZQ882 (1600209, 6 May 2016).

2 Section 6. Labels are given by the labelling body but when it has trouble classifying a publication it will be referred to the Office of Film and Literature Classification (Office). Exceptions are in ss 7 and 8 and include government sponsored and general educational films: for example, scientific or religious films.

3 FVPC Act, ss 8(2) and 13.

4 Sections $76-77$.

5 Section 23.

6 Section 47.

7 Sections 58 and 70. 
The main discussion of whether a publication is objectionable occurs under s 3 of the FVPC Act. Section 3(1) defines a publication as objectionable if it "describes, depicts, expresses, or otherwise deals with matters such as sex, horror, crime, cruelty, or violence" in a manner that is likely to injure the public good. Under the original legislation this was the sole "gateway" provision: if the relevant publication did not deal with material under the s 3(1) definition, then that publication could not be deemed to be objectionable. Once a publication fell within the gateway, however, it could be classified in any way which was permitted under s 23 (and still can be today). Section 3(2) provides a number of circumstances under which a publication will definitely be classified as objectionable. ${ }^{8}$ If a publication does not fall under any of the s 3(2) headings, the classification must be considered with particular weight given to matters in s 3(3) which include sexual and physical violence and criminal acts, ${ }^{9}$ and with a lesser level of consideration given to the matters in s 3(4) which include the dominant effect of the publication and the target audience. ${ }^{10}$ Under s 4 of the FVPC Act, the Office and Board do not have to take into account any evidence or proof relating to the matter at hand, but should take it into account if it is available.

\section{A Impact of Living Word}

The case of Living Word Distributors Ltdv Human Rights Action Group (Living Word) concerned the classification of two videos addressing LGBT issues. ${ }^{11}$ There was an issue as to whether the videos fitted within the gateway provision in s 3(1) of the FVPC Act. The Office initially classified the videos as R18, stating that although the videos did not depict specific matters of sex, horror, crime, cruelty or violence they could be brought within the definition of "objectionable" under the Act. ${ }^{12}$ The Board classified both videos as objectionable. ${ }^{13}$ The Court of Appeal, however, found that the qualifiers under s 3(1) restricted the gateway solely to subjects listed in the statute. ${ }^{14}$ Moreover, the publication would have to depict actions of those subjects, not merely opinions concerning them. ${ }^{15}$

This judgment significantly narrowed the gateway provision of s 3(1) and sparked debate about how far the powers of the Office and Board could really extend. A publication could no longer be classified unless it dealt specifically with one of the five topics under s 3(1). A Government

8 Section 3(2)(a).

9 Section 3(3)(a) and (d).

10 Sections 3(4)(a) and (d).

11 Living Word Distributors Ltd v Human Rights Action Group Inc (Wellington) [2000] 3 NZLR 570 (CA) at [2].

12 At [4] and [22].

13 At [6].

14 At [27].

15 At [28]. 
Administration Committee inquiry into the legislation after Living Word expressed concern about uncertainty of the jurisdiction of the Office in areas concerning nudity, offensive language, invasion of privacy or mental illness. ${ }^{16}$ Ultimately there was a review of the legislation.

The Films, Videos, and Publications Classification Amendment Act 2005 contained a number of provisions which clarified some of the areas where Living Word had created confusion. Among the new additions to the FVPC Act was s 3A:

3A Publication may be age-restricted if it contains highly offensive language likely to cause serious harm

(1) A publication to which subsection (2) applies may be classified as a restricted publication under section $23(2)(\mathrm{c})(\mathrm{i})$.

(2) This subsection applies to a publication that contains highly offensive language to such an extent or degree that the availability of the publication would be likely, if not restricted to persons who have attained a specified age, to cause serious harm to persons under that age.

(3) In this section, highly offensive language means language that is highly offensive to the public in general.

There is an element of discretion here: once the relevant body is satisfied there is highly offensive language, to such an extent or degree that it is likely to cause serious harm, it "may" age-restrict the publication. Even if the threshold is met, there is still an option to not place any restriction on the publication. However, the decision cannot be made arbitrarily: discretion ought to be exercised responsibly and in the public interest. ${ }^{17}$ The Office and Board, when exercising this discretion, should therefore also consider the public interest in the publication and its availability alongside the public interest in reducing the harm to society stemming from language use.

Alongside s 3A, the amendment introduced ss 3B-3D. Section 3B allows age restriction of a publication for specific reasons such as content detailing self-harm or degrading physical conduct. ${ }^{18}$ The legislation was passed with the intent of avoiding the narrowly interpreted gateway provision of s 3(1). When the amendment was first introduced into Parliament it was framed in the context of clarifying doubts raised by Living Word and extending the categories under which the Office and Board could restrict a publication. ${ }^{19}$ Section $3 \mathrm{D}$ clarifies this by stating that ss $3 \mathrm{~A}$ and $3 \mathrm{~B}$ are not limited by $\mathrm{s} 3$.

16 Government Administration Committee Inquiry into the Operation of the Films, Videos, and Publications Classification Act 1993 and related issues (5 March 2003) at 16.

17 Timothy Endicott Administrative Law (3rd ed, Oxford University Press, Oxford, 2013) at 242.

18 FVPC Act, s 3B(3)(a)(i) and (iii).

19 (2 March 2004) 615 NZPD 11457. 


\section{APPROACH OF THE OFFICE}

The approach of the Office to the application of s 3A has been somewhat inconsistent since the section was introduced. ${ }^{20}$ There is a lack of regularity in which words are considered highly offensive and which harm is deemed serious, and the NZBORA is not so much applied as mentioned in passing. The decisions themselves are reasonably similar in their layout. The Office begins with a synopsis of the publication, and moves on to consider the publication under the s 3(1) gateway and, if applicable, the matters under s $3(2)$, and then with respect to ss $3 \mathrm{~A}$ and $3 \mathrm{~B}$. The Office will then usually consider the relevant matters under s 3(4), and in an overall conclusion weigh up the total potential harm of the publication and the likelihood of injury to the public good in order to reach a final decision on the rating. It undertakes a much more detailed analysis with books and other miscellaneous mediums than with films.

\section{A Interpretation of "Highly Offensive"}

When applying s 3A, the Office must first establish whether there was use of highly offensive language. The Office's decision will usually identify the relevant offensive language and give some examples, most commonly "fuck" and its derivatives. However, the reasons behind the classification of the language as "highly offensive" vary. In the documentary Pearl Jam Twenty, the word "fuck" was considered to be "offensive in nature", indicating that no matter where it is used it will be considered to qualify as highly offensive language under 3A. ${ }^{21}$ Similarly, in its review of the book Down Under the Plum Trees, the Office stated that the use of words such as "fuck" and "cunt ... have never been fully accepted as legitimate in material intended for public consumption", which is further evidence that the Office may consider such words as naturally highly offensive. ${ }^{22}$

However, there have been a few rare cases where the Office does not consider the use of such words as highly offensive. Despite previous indications that words such as "fuck" are offensive in their very nature, the Office takes a different route and considers other factors which could change whether the words used were highly offensive to the public in general. In The Message, a spy thriller film containing multiple torture scenes, the Office held that the use of the word "fuck" was not highly offensive, as its use under the circumstances was not "particularly unwarranted": it is not unreasonable

20 Information for this section was gathered by looking at reports from the Office on age-restricted publications, as well as some which were objectionable. The research covered decisions from 2008 to the present on the online database of decisions found at <www.classificationoffice.govt.nz〉. A selection of 30 films were reviewed, with an aim to include a proportionate amount of age restrictions and years. All books containing an age restriction and/or an offensive language warning were reviewed, as well as other miscellaneous publications which were likely to discuss issues under s $3 \mathrm{~A}$

21 OFLC Pearl Jam Twenty (1100878, 31 August 2011) at 1.

22 OFLC Down Under the Plum Trees (1400241, 9 December 2014) at 9. 
to expect offensive language when a person is being tortured. ${ }^{23}$ In that case, the Office appeared to take into account the context in which the word was used as a contributing factor to how offensive it would be. Similarly, in the book Bloody Mama, which concerned the life of a criminal matriarch and the exploits of her family, the word "fuck" was only referred to as "coarse language" and was "not likely to ... be considered 'highly offensive"' because it was used infrequently. ${ }^{24}$ In that case the Office seemed to find the language less offensive because it was used less often, despite the fact that the word itself could be deemed to be offensive in its own right according to some of its previous statements.

What appears to be happening in these anomalous cases is a confusion between what is relevant when assessing whether language is highly offensive. Is it necessary to refer only to individual words and phrases which, regardless of the context, could be considered offensive in their own right? Or should there be an examination of the context in which the language is used? The Office has taken both approaches at various points in time, although it seems to prefer the first.

\section{$B$ Investigation of Harm}

More inconsistencies appear when the Office addresses the issue of harm arising from use of highly offensive language. The language must be used to "such an extent or degree" in the relevant publication that it would be likely to cause "serious harm" to a viewer under the recommended age. ${ }^{25}$ However, the Office does not always address the issue of harm.

In some cases, the Office will identify highly offensive language in the publication but will not go on to consider the harm that could result from the use of the language. There may simply be a statement that the use of highly offensive language supports a restriction. ${ }^{26}$ In some reports, there is a mention of the context in which the language is used that indicates "extent and degree" analysissuch as the frequency with which the language is used, whether it is used aggressively, threateningly, sexually, or humorously, or the general impact of the language - but there is no mention of whether there is any possible harm resulting from the extent or degree of use. ${ }^{27}$ In some reviews, the Office conducts a general discussion of harm in the conclusion of their findings, but does not always mention harm specifically as it relates to highly offensive language. For instance, in the report of the film Fifty Shades of Grey, the harm discussion does not refer to offensive language, only to sexual activity,

23 OFLC The Message (0901368, 30 September 2009) at 2.

24 OFLC Bloody Mama (1101225, 13 February 2002) at 7.

25 FVPC Act, s 3A(2).

26 See for example OFLC The Book of Eli (1000074, 28 January 2010) at 2; OFLC The Grey (1200173, 21 March 2012) at 3; and OFLC Grimsby (1500948, 25 February 2016) at 3.

27 See for example OFLC Fifty Shades of Grey (1200609, 20 September 2012) at 8; OFLC TT3D: Closer to the Edge (1100868, 19 August 2011) at 1-2; OFLC Deadpool (1600044, 10 February 2016) at 3; and OFLC Revolutionary Road (0802501, 17 December 2008) at 2. 
despite the Office finding that there was some use of highly offensive language. Thus, the requirements of s $3 \mathrm{~A}$ are not always fully discussed.

There are a number of cases in which the Office does identify harm that arises from the frequent use of offensive language. In most cases, the harm identified is inuring children to offensive language and encouraging its use. ${ }^{28}$ In some cases the harm goes further, with the Office stating that if children become desensitised they could use the language inappropriately, leading to alienation or a damaging impact on socialisation. ${ }^{29}$ When offensive language is used in a particularly aggressive or threatening manner, the Office has identified a harm of disturbing children or causing distress but does not cite any research in its reports. ${ }^{30}$

Moreover, the level of harm which the Office attributes to consequences varies. Occasionally it states the possible consequence of the language use in the film without identifying how serious the harm really is. ${ }^{31}$ In some cases, the desensitisation of young people to offensive language and resulting emulation is called an "adverse effect" rather than an outright harm. ${ }^{32}$ This could be the Office simply substituting one term for another, but "adverse effect" does not really indicate that the consequence is of the same severity as a "serious harm".

In other reports, the Office has referred to normalisation of highly offensive language as a harm that is not serious enough to warrant an age restriction. ${ }^{33}$ But in several reviews, the Office explicitly identifies normalisation and encouragement of use of highly offensive language, or the alienation or intimidation which could result from such encouragement, as a "serious harm". ${ }^{34}$ The reason behind these conflicting reports could be connected with the type of publication that the Office is classifying. When a publication contains material of a violent or sexual nature alongside offensive language, the use of offensive language could be associated with that material and result in the perception that there is quite significant harm attached to the normalisation of using offensive language in general.

28 See for example OFLC Zombieland (0901410, 16 October 2009) at 3; OFLC The Master (1201057, 5 December 2012) at 2; and OFLC Predators (1001135, 2 July 2010) at 2.

29 See for example OFLC American Psycho (1400246, 2 July 2014) at 7; OFLC The Dictator (1200347, 1 May 2012) at 2; and OFLC Unfinished Business (1500092, 3 March 2015) at 2.

30 See for example OFLC Southpaw (1500517, 17 July 2015) at 2; and American Psycho, above n 29, at 7.

31 See for example OFLC Safe (1200424, 29 May 2012) at 2; OFLC Ex Machina (1500108, 10 March 2015) at 2; and OFLC Slow West (1500142, 16 March 2015) at 2.

32 OFLC The Bling Ring (1300573, 24 June 2013) at 2; and Southpaw, above n 30, at 2.

33 OFLC Go the Fuck to Sleep (1100691, 8 August 2011) at 6; and Pearl Jam Twenty, above n 21, at 1.

34 See for example Zombieland, above n 28, at 3; Unfinished Business, above n 29, at 2; and The Master, above n 28 , at 2 . 
However, when a publication contains offensive language without other offensive or harmful material, the idea of normalising the language does not seem quite as serious.

For example, in Go the Fuck to Sleep, a book for adults presented as a children's bed-time story, the only complaint was the frequent (but comedic) use of highly offensive language. ${ }^{35}$ It was rated unrestricted. The Office identified the use of highly offensive language and the possibility of children or young people being inured to it, but considered the harm mitigated by the responsibility of parents and caregivers to control the content viewed by children. However, reports which identified emulation as a serious harm also usually had content warnings for various combinations of violence or graphic violence, sexual references, nudity and drug use. ${ }^{36}$ Thus the offensive language was used more often or in a more threatening, aggressive or derogatory way than if it was only used casually or humorously. Any consequences from emulating this kind of language could seem harsher as a result.

The many different ways in which the Office classifies harm leads to some confusion: for instance, desensitisation to and encouragement of highly offensive language is sometimes considered a serious harm and sometimes something less. The approach that the Office takes towards categorising the level of harm resulting from desensitisation or emulation should remain constant. ${ }^{37}$

\section{Application of the NZBORA}

The Office probably did not discuss the NZBORA in its classification of films until around $2013 .^{38}$ However, it has always been referred to when considering other publications. Usually the relevant provisions of the NZBORA (ss 14, 5, and 6) are set out and any discussion is in the form of one or two sentences in the general conclusion once all the relevant factors have been considered under ss 3, 3A and 3B of the FVPC Act.

The sentences have varying phrasing but all tend to indicate that the Office has decided that the restriction is justifiable (or not, as the case may be). ${ }^{39}$ Sometimes it will mention weighing the protections under the NZBORA against the harm resulting from the publication, ${ }^{40}$ or that to place a

35 Go the Fuck to Sleep, above n 33; and see also Pearl Jam Twenty, above n 21.

36 See for example The Dictator, above n 29; The Master, above n 28; Unfinished Business, above n 29; and Zombieland, above n 28.

37 American Psycho, above n 29, at 7.

38 There is a possibility that the Office did consider the New Zealand Bill of Rights Act 1990 (NZBORA) in its film decisions before 2013, but it did not do so in any of the decisions used for this research. Given the relative consistency of the structure of decisions, it seems unlikely that any other decisions would contain an NZBORA discussion.

39 See for example Go the Fuck to Sleep, above n 33, where a restriction was not justified with mention of the NZBORA; and American Psycho, above n 29, where a restriction was justified.

40 OFLC Last Exit to Brooklyn (1400235, 4 September 2014) at 12. 
certain restriction would be an unnecessary limit on the right to freedom of expression. ${ }^{41}$ Usually these sentences will come immediately before or after a discussion of whether the publication can be injurious to the public good.

Occasionally the Office recognises that its decision is inconsistent with freedom of expression. However, it goes on to state that because the FVPC Act allows it to restrict publications which are injurious to the public good, the inconsistency is justified. ${ }^{42}$ In doing so, the Office treats the two Acts as though they are mutually exclusive: if one applies, the other cannot. They fail to balance harms and benefits under the NZBORA, and consequently do not apply their discretion to reasonably limit a right under s 5 of the NZBORA in the least restrictive way possible.

When the Office does mention the NZBORA it does so in a very general manner - there is usually only one short discussion which encompasses the harm of all three sections under which a publication can be restricted. This means that it becomes unclear whether a publication is restricted under ss 3 , 3A, or 3B. Most often it appears to be a combination of multiple sections, particularly ss 3 and $3 \mathrm{~A}$. However, these sections have slightly different tests: s 3 requires a test considering whether the publication is likely to be injurious to the public good, while s $3 \mathrm{~A}$ requires the publication to cause serious harm to younger viewers. Each provision has a slightly different purpose and requires a slightly different approach under the NZBORA, or at least clarification as to how the relevant restriction is being justified. In its more recent decisions concerning Wicked Campers, the Office has moved towards this kind of discussion. In its conclusion it makes specific reference to $\mathrm{s} 3 \mathrm{~A}$ and states a restriction would "be neither reasonable nor justified" under that specific section. ${ }^{43}$ This approach appears to be unique to the Wicked Campers series of decisions, but if it were more widely adopted it could improve the quality of decisions produced by the Office and the Board.

\section{APPROACH OF THE BOARD}

The Board's approach to applying s 3A has changed with its leadership. ${ }^{44}$ Until 2010, the Board's decisions were laid out under headings relating specifically to each part of the legislation. In many cases where s 3A was irrelevant it would not be included in reports. ${ }^{45}$ After a change of leadership in 2010 the Board's approach became less formally structured, meaning that at times it is unclear which

41 Down Under the Plum Trees, above n 22, at 11.

42 See for example Slow West, above n 31, at 2

43 Wicked Camper DZQ882, above n 1, at 11.

44 The President of the Film and Literature Board of Review (the Board) changed to Dr Don Mathieson in 2010 Nathan Guy "New Appointments to Film and Literature Board of Review" (29 June 2010) The Beehive <www.beehive.govt.nz>. All decisions involving offensive language from 2008 to present were examined, accessed via the Department of Internal Affairs <www.dia.govt.nz>.

45 See for example the Board "End of the Spear" (2 July 2008) Department of Internal Affairs $<$ www.dia.govt.nz>: a film with no offensive language and no mention of $\mathrm{s} 3 \mathrm{~A}$ in the report. 
section of the legislation is being addressed. When it does discuss s $3 \mathrm{~A}$, the Board identifies language but rarely refers to the harm that results from it. The NZBORA is not consistently discussed in more recent decisions.

\section{A Discussion of $\mathrm{s} 3 \mathrm{~A}$}

When it discusses s 3A, the Board has with relative consistency identified certain words as "highly offensive" in a similar manner to the Office, mainly "fuck" and its derivatives. ${ }^{46}$ In some reports the language is commented on as being offensive, but is not mentioned in the context of s $3 \mathrm{~A}$ and no further analysis is undertaken. ${ }^{47}$ The Board does not call any word inherently offensive, but it also does not enter into a discussion of whether context makes a word more or less offensive. This could indicate that the board is taking certain expletives to be inherently offensive, similar to the main approach of the Office.

The Board's discussion of harm has been almost non-existent. In two decisions it has restricted a publication under s 3A and neither restriction contains a discussion of harm. In the first, the game Grand Theft Auto IV (unedited version) was classified R18 based on the term "mother fucker" as well as other expletives being highly offensive and likely to cause serious harm. ${ }^{48}$ When identifying harm, the Board referred to the Office's research as authority for the fact that the term "mother fucker" was of limited social acceptance, but did not further explain any form of potential serious harm. ${ }^{49}$ In the second decision, the film Black Mass was classified R16. This decision was somewhat unique as the Board stated that it was unnecessary to apply the entirety of the law since ss $3 \mathrm{~A}$ and $3 \mathrm{~B}$ both clearly applied. ${ }^{50}$ However, the Board merely identified the word "fuck" and its derivatives as highly offensive and stated that they were used to express anger and intimidate. ${ }^{51}$ No serious harm was discussed at all.

\section{B Application of the NZBORA}

In its pre-2010 decisions, the Board included at the end of its decision a lengthy boilerplate passage describing the decision and the five-step test laid out in Moonen $v$ Film and Literature Board

46 See for example the Board "Two Little Boys" (14 September 2012) Department of Internal Affairs $<w w w . d i a . g o v t . n z>$ at [10].

47 At [10].

48 The Board "Grand Theft Auto IV (Unedited Version)" (17 September 2008) Department of Internal Affairs $<w w w . d i a . g o v t . n z>$ at [94].

49 At [94].

50 The Board "Black Mass" (12 October 2015) Department of Internal Affairs <www.dia.govt.nz> at [9] and [11].

51 At $[10]$. 
of Review. ${ }^{52}$ Essentially the Board laments the difficulty of applying the test but attempts to do so anyway. What results is a brief discussion of the importance of freedom of expression and the purpose of the FVPC Act to protect the general public, finished with a statement that the restriction placed by the Board is justified. It appears to be a more long-winded version of the Office's interchangeable statements concerning consideration of the NZBORA: an attempt to make it clear that there has been application, but no in-depth analysis. Additionally, this systematic approach does not consider the separate sections but the legislation as a whole, which is (as mentioned above) a failure to recognise the different standards set by the sections of the legislation.

In decisions after 2010, the Board has been sporadic in its mentions of the NZBORA, moving more towards the approach of the Office. When classifying the film Two Little Boys the Board did not mention the NZBORA. ${ }^{53}$ The film The Girl with the Dragon Tattoo received its R16 rating under s 3B with the Board "having regard to" freedom of expression. ${ }^{54}$ This shows that the Board at least considered the importance of the NZBORA in their decision, although it is unclear as to how.

However, in its decision in Black Mass the Board stated that, while it was "conscious of" rights under the NZBORA, s 3A "plainly applies and limits that right". ${ }^{55}$ Similarly to the Office, the Board occasionally mentions the NZBORA as though it is expressly overridden by s $3 \mathrm{~A}$ (or the FVPC Act in general), but as previously stated this approach ignores the balancing required by the NZBORA in order to find the least restrictive limitation of the right.

\section{Summary and Comparison}

Overall the approach of both the Board and the Office to the application of s 3A has been inconsistent. In some cases, especially in decisions of the Office, certain words are considered naturally offensive and in others the same words are not. Sometimes there is no discussion of the extent and degree of the language, or there is no discussion of harm. While the Office at times gives very detailed discussion of highly offensive language and the harm thereof, it also often fails to do so adequately, or in a manner that is consistent and predictable. The Board often fails to discuss harm in any manner whatsoever. While the NZBORA is usually always considered (with a few exceptions by the Board), the way it is applied does not always have the same level of consistency and it is occasionally ignored completely by both the Office and the Board when they state that its inconsistency with the FVPC Act effectively binds their decisions.

52 See for example "Grand Theft Auto IV (Unedited Version)", above n 48, at [95]-[103]. The test can be found in Moonen v Film and Literature Board of Review [2002] 2 NZLR 9 (CA) at [17]-[18].

53 "Two Little Boys", above n 46.

54 The Board "The Girl with the Dragon Tattoo" (10 February 2012) Department of Internal Affairs $<w w w . d i a . g o v t . n z>$ at [17].

55 "Black Mass", above n 50, at [12]. 
The approaches of the Office and Board raise a number of issues. There is much consistency to be desired in their approach to interpreting offensive language and serious harm, and the application of the NZBORA is minimal. However, if the Office and Board recognise relevant research and take a more in-depth approach to the NZBORA, it is suggested that the considerations and balancing this requires could lead to an approach that is more regulated and predictable.

\section{RESEARCH SURROUNDING HIGHLY OFFENSIVE LANGUAGE}

In order to properly and consistently assess whether an age restriction is justified under s $3 \mathrm{~A}$, the Office must have an accurate understanding of what constitutes highly offensive language.

\section{A Offensive Language}

The analysis of harm under s $3 \mathrm{~A}$ is only triggered once there is use of "highly offensive language". However, most scholars accept that language in general has no inherent moral meaning. ${ }^{56}$ Words are simply words: yet in our society some words cause more offense than others. It is not the words themselves that are offensive, but the ideas that they convey, which we learn through socialisation. ${ }^{57}$

Since socialisation plays such a large part in the level of offensiveness attached to a word, culture is a major factor in whether a word is found offensive. Research by New Zealand's Broadcasting Standards Authority (BSA) assesses the level of offensiveness attached to words in New Zealand, and their report is a good starting point for assessing their acceptability in publications. ${ }^{58}$ From this report it can be seen that in New Zealand the most offensive terms are usually ethnic slurs and sexual language, while religious and excretory profanity are more acceptable. In recent years, audiences have become more tolerant of offensive language. ${ }^{59}$ However, social science research indicates that there are a number of factors which impact the offensiveness of language beyond its social acceptability.

\section{B Aggravating and Mitigating Factors}

Various amounts of research have shown that different words have different levels of offensiveness, and even the same word can be more or less offensive depending on particular circumstances.

56 Timothy Jay "Do Offensive Words Harm People?" (2009) 15(2) Psychology, Public Policy, and Law 81 at 81; Christopher M Fairman "Fuck" (2007) 28 Cardozo L Rev 1711 at 1724; Melanie C Burns "Why We Swear: The Functions of Offensive Language" 6 MULP 61 at 61; and Dale L Cressman and others "Swearing in the Cinema: An analysis of profanity in US teen-oriented movies, 1980-2006" (2009) 3(2) Journal of Children and Media 117 at 119.

57 Cressman and others, above $\mathrm{n} 56$, at 120; and Burns, above $\mathrm{n} 56$, at 66

58 See Broadcasting Standards Authority "What Not to Swear: The Acceptability of Words in Broadcasting" (September 2013) Broadcasting Standards Authority <www.bsa.govt.nz〉.

59 Nielsen "Litmus Testing 2016" (July 2016) Broadcasting Standards Authority <www.bsa.govt.nz> at 41. 
Swearing can be intentional or unintentional, and it is intentional swearing which has the highest potential to be offensive. ${ }^{60}$ Swearing that is unintentional — for example, as a response to pain - is less likely to offend and more likely to be seen as an emotional outburst. ${ }^{61}$ In contrast, swearing which is intentional can be purposefully polite or impolite, and so have a more definite impact on the level of offense caused. ${ }^{62}$ Therefore the offensiveness of a taboo word depends on how intentional its use was.

When taboo language is used intentionally, its level of offensiveness can vary depending on the situation. One major factor in the level of offense is in the social setting. Taboo language can be used in group settings to include or ostracise people, and there are certain situations where it will be far less suitable to use: for instance, one is more likely to hear taboo words in a relaxed setting at a pub than in an office environment. ${ }^{63}$ An environment where parties are more relaxed and socially equal is an environment where taboo language is less offensive. ${ }^{64}$ Additionally, ethnicity is also closely linked to the acceptance of particular words. One study has found that highly offensive racial slurs are even more offensive when used by a person who does not belong to the ethnic group towards which the slur is aimed. ${ }^{65}$ The social environment in which the swearing takes place, including social class and ethnicity, also has an impact on offensiveness.

Intentional swearing can also be more offensive when it is used to be purposefully impolite. When it is used to attack or bully someone or to gain power over another person, it can be seen as more offensive than if it is used to describe something positive. ${ }^{66}$ Thus the situation and context of the event in which the swearing takes place can make the use of language either more or less offensive.

\section{Implications}

Currently the Office and Board both lean towards identifying some words, mostly "fuck" and its derivatives, as inherently highly offensive. This is an approach which is not supported by the current research. While some words are definitely not socially acceptable to New Zealanders - and some

60 Timothy Jay and Kristin Janschewitz "The Pragmatics of Swearing" (2008) 4 Journal of Politeness Research 267 at 270.

61 At 270 .

62 At 270 .

63 Burns, above n 56, at 64; and Jay and Janscewitz, above n 60, at 273.

64 Jay and Janscewitz, above n 60, at 273.

65 Lora Jacobi "Perceptions of Profanity: How Race, Gender, and Expletive Choice Affect Perceived Offensiveness" (2014) 16 North American Journal of Psychology 261 at 261.

66 Jay and Janscewitz, above n 60, at 270. 
more offensive than others - there are a number of factors which should be taken into account when a word is being defined as meeting the threshold of "highly offensive".

When analysing the language in a film, the Office and Board could first look to the research of the Broadcasting Standards Authority to discern whether any of the language could be considered offensive by New Zealand standards. Then they should further investigate whether that language could truly be considered "highly offensive to the public in general" by looking to the context in which the language was used.

Language will be less offensive if used involuntarily as an expression of emotion, in a positive or humorous manner, or in a casual setting between equals. It will be more offensive if used intentionally in a setting where there is a level of formality or social inequality, or in a manner which is violent, degrading, or dominating. A word which is considered more naturally offensive may not need as many aggravating factors to be considered offensive, while a word that is relatively socially acceptable may need to meet a higher threshold to be considered highly offensive under the FVPC Act.

The Office has already undertaken this approach to an extent in some of its decisions, including some of its 2016 reports on Wicked Campers. ${ }^{67}$ However, the Board continues to classify words as "highly offensive" despite their context. For instance, it terms "wankers" as highly offensive even though its use in Into the River was amongst a group of schoolboys, a casual setting where such language is common. ${ }^{68}$ A proper discussion of the context of the language would help to align the decisions of the bodies and make them more accurate.

\section{RESEARCH SURROUNDING SERIOUS HARM}

While the Board has neglected to address harm in almost every case, the Office has identified some forms of harm such as encouraging increased use of offensive language and becoming shocked or disturbed. This harm has not been identified as serious consistently. A closer observation of research surrounding the harm resulting from highly offensive language could result in better understanding of what really constitutes serious harm and what would not be a harm capable of justifying a restriction. There are a number of possible types of harm that can result from the use of offensive language both for those who are hearing the language and for those who are using it.

\section{A Increased use of Offensive Language}

The Office frequently identified increased use of offensive language as a harm in and of itself resulting from exposure to highly offensive language. ${ }^{69}$ Research indicates that increased exposure to a practice or idea in the media could result in the viewer echoing that behaviour. Cultivation theory

67 See for example Wicked Camper DZQ882, above n 1, at 8.

68 See the Board "Into the River" (2013) Department of Internal Affairs <www.dia.govt.nz> at [33].

69 See for example The Master, above n 28; and The Dictator, above n 29. 
suggests that heavy exposure to media messages will help to shape a person's view of reality, while social learning theory suggests that humans learn not only through personal experience but through observation of external sources, including the media. ${ }^{70}$ Since young people are still developing behavioural constructs, they can be particularly vulnerable to media messages, including use of highly offensive language. ${ }^{71}$ They can especially become desensitised to the use of such language and increase its use in their own personal lives. ${ }^{72}$

However, the use of offensive language is not always harmful in and of itself. Research has shown that it can even be beneficial at times. Swearing is linked to a separate part of the brain than ordinary language and is strongly tied to emotional responses. ${ }^{73}$ It can be used to communicate emotions that cannot be expressed with regular language. ${ }^{74} \mathrm{~A}$ verbal outlet of emotion can also be a preferable alternative to physical expression of frustration. ${ }^{75}$ There is even evidence to suggest that swearing heightens a person's pain threshold under certain circumstances - although this only works for those who do not swear frequently already. ${ }^{76}$

It is evident that swearing can come in appropriate and inappropriate forms. ${ }^{77}$ As a result, more frequent use of highly offensive language will not always be seriously harmful in and of itself, and can even be positive. ${ }^{78}$ However, increased use of offensive language can be linked to other types of harm, as outlined in the remainder of this part. If language is used frequently, particularly in an inappropriate manner, its increased use could lead to these more serious forms of harm.

\section{B Social Embarrassment}

When s 3A was passed in 2005, the Office conducted its own research to determine the level of harm that might occur from the use of highly offensive language. It surveyed members of the public to determine potential harm, and the general consensus was that offensive language was capable of

70 Cressman and others, above n 56, at 118 .

71 Sarah M Coyne and others "Profanity in Media Associated with Attitudes and Behaviour Regarding Profanity Use and Aggression" 128 Pediatrics 867 at 868.

72 At 868

73 Timothy Jay "The Utility and Ubiquity of Taboo Words" (2009) 4 Perspectives on Psychological Science 153 at 155; and Burns, above n 56, at 67.

74 Jay, above n 73 , at 155 .

75 At 155 .

76 See Richard Stephens, John Atkins and Andrew Kingston "Swearing as a Response to Pain" (2009) 20 NeuroReport 1056; and Richard Stephens and Claudia Umland "Swearing as a Response to Pain - Effect of Daily Swearing Frequency" (2011) 12 Journal of Pain 1274.

77 Jay, above n 73, at 155 .

78 At 155 
causing harm to the young people that used it, but it was mainly an issue of public image. ${ }^{79}$ If young people were heavily exposed to offensive language in the media then it could become normalised and lead to more frequent use by young viewers, which could in turn lead to inappropriate use of the language. ${ }^{80}$ According to the participants, this could lead to embarrassment or a lack of respect for the young person using the language. ${ }^{81}$ They observed that it was important for children to learn when it was and was not appropriate to use offensive language, and showed particular concern where offensive language was used to attack or degrade others as opposed to when it was used casually or in humorous circumstances. ${ }^{82}$

Scholars have identified the possible interpersonal costs of increased swearing including speaker credibility and prejudice stemming from use of offensive language in inappropriate circumstances. ${ }^{83}$ However, it is questionable as to whether this harm is "serious" enough to warrant restriction.

\section{Emotional Distress}

While there is no evidence of emotional harm from the use of conversational or cathartic swearing, there is a possibility that some emotional distress could be caused by harassment, discrimination or other forms of offensive language which are aimed directly at a person. ${ }^{84}$ Verbal aggressiveness can cause psychological pain, embarrassment, and feelings of despair and inadequacy, but it is important to note that verbal aggressiveness is not necessarily limited to offensive language; it can also include hurling insults and making threats which do not include language that would necessarily be classed as highly offensive. ${ }^{85}$ In such cases the publication could probably be classified under the "cruelty" gateway of s 3 .

All research in this area has been undertaken in situations where there is direct communication between an abuser and a victim. ${ }^{86}$ Therefore the harm that could result from a young person feeling

79 Office of Film and Literature Classification and UMR Research Ltd "Public Perceptions of Highly Offensive Language" (November 2007) <www.classificationoffice.govt.nz> at 10.

80 At 10 .

81 At 10 and 26-27.

82 At 63.

83 Jay, above n 73, at 160; and Burns, above n 56, at 67.

84 Jay, above n 56, at 93.

85 Dominic A Infante and others "Verbal Aggressiveness: Messages and Reasons" (1992) 40 Communication Quarterly 116 at 116; and Annette R Pejic "Verbal Abuse: A Problem for Pediatric Nurses" (2005) 31 Pediatric Nursing 271 at 271.

86 In Jay, above n 56, Jay focuses on offensive telephone calls; in Infante and others, above $\mathrm{n} 85$, the focus is on interactions between students; and in Pejic, above $\mathrm{n} 85$, the focus is on interactions between nurses and patients. 
victimised by a message that they see in a publication may not be as distinct or serious as if they were being personally abused. At this point research in this area is lacking, primarily because of the difficulty of gathering any information in an ethical manner. ${ }^{87}$

\section{Physical Aggression}

There has been one study which loosely links an increased exposure to highly offensive language to relational and physical aggression. The study involved a survey of 223 middle school students in the United States of America, and found correlation between increased levels of offensive language in media and more casual views about offensive language in general. ${ }^{88}$ This in turn was linked to an increase in use of offensive language, which was finally linked to increased instances of physical and relational aggression. ${ }^{89}$ The results found no proof of causation however and there do not appear to have been many other studies in this area to either confirm or deny the results. ${ }^{90}$ Still, the possibility of increased aggression as a result of offensive language could be one that may become more relevant in the future, and physical aggression could propose a more serious harm to be taken into consideration.

\section{E Implications}

The Office has identified nearly all the listed types of harm in its reports. However, it sometimes does not mention harm at all and the Board even less so, despite the requirement of "serious harm" in the legislation. ${ }^{91}$ Additionally, the seriousness that the Office attaches to any harm tends to fluctuate. It is suggested that by incorporating the relevant research into their reports, the Office and Board can come to more consistent conclusions surrounding the harm resulting from offensive language.

When discussing harm, the Office and Board could look to both the frequency and context of the offensive language. If a publication has a large amount of offensive language in it, children will be more likely to emulate the language. However, this on its own is probably not enough to be considered "serious harm". Something more is needed, such as social embarrassment or emotional harm. If the language used is mostly in socially inappropriate situations such as formal outings or when threatening someone, it is more likely to be emulated in an improper way so could cause more social embarrassment than if it were used in more acceptable conditions such as in a casual situation. Similarly, if language is used in a way that could cause a viewer to feel personally attacked, such as when aimed towards a specific ethnic or religious group, it would be more likely to cause emotional

87 Cressman and others, above n 56, at 121.

88 Coyne and others, above n 71, at 868-869.

89 At 869.

90 At 871 .

91 FVPC Act, s 3A. 
harm than if it was aimed at a particular character or used as an expression. The higher the frequency of language specific to this harm, the more serious the potential overall harm.

Deciding whether a harm is a serious one is not a straightforward consideration, especially when publications can have other content which might cause injury to the public. As well as considering the frequency with which the particular language causing the harm arises, the Office and Board could consider the effect that social conditioning and parental control have on curbing any harm. Finally, the Office and Board should take a more detailed and consistent approach to the NZBORA in order to determine whether a harm is serious enough to warrant a restriction of rights.

\section{SIGNIFICANCE OF THE NZBORA}

Given the nature of its powers and its ability to restrict the freedom of expression, the Office and Board must consider the NZBORA. A proper discussion could also assist in reaching decisions that have a more in-depth and consistent discussion of harm.

\section{A Applying the NZBORA}

The NZBORA applies to bodies in the performance of any public function, power or duty that is conferred or imposed by law. ${ }^{92}$ The Office and Board make decisions under authority given to them by statute, which brings them within the scope of the NZBORA. ${ }^{93}$ When restricting a publication under s $3 \mathrm{~A}$, the Office and Board restrict the freedom of expression of the creator of the publication, as well as the ability of the general public to access, analyse and discuss it. Such rights and freedoms are protected under s 14 of the NZBORA. ${ }^{94}$

Section 6 of the NZBORA requires that enactments should be read, where they can, as having a meaning consistent with the freedoms contained within the Act. In the past this has been used in situations such as Moonen where there are multiple interpretations of the FVPC Act available and the Office and Board must choose which one to apply. ${ }^{95}$ However, s 6 also requires more generally that statutes ought to be read subject to the NZBORA unless it is clear from the context that they cannot be. ${ }^{96}$ This means that it applies not only to interpretation of words in the legislation, but to the decision

92 New Zealand Bill of Rights Act 1990, s 3.

93 The Office and the Board were created by ss 76 and 91 of the FVPC Act respectively. See also Moonen $v$ Film and Literature Board of Review, above n 52, at [28]; and the pre-2010 boilerplate used by the Board: see for example "Grand Theft Auto IV (Unedited Version)", above n 48, at [96]-[97].

94 Section 14 states "[e]veryone has the right to freedom of expression, including the freedom to seek, receive, and impart information and opinions in any kind in any form".

95 Moonen, above n 52, at [28]. See also $R v$ Hansen [2007] NZSC 7, [2007] 3 NZLR 1.

96 Claudia Geiringer and Steven Price "Moving from Self-Justification to Demonstrable Justification - the Bill of Rights and the Broadcasting Standards Authority" in Jeremy Finn and Stephen Todd (eds) Law, Liberty, Legislation (LexisNexis, Wellington, 2008) 295 at 302-303. The research in this chapter refers specifically 
making process undertaken when classifying publications, which is often an assessment of degrees of infringement rather than comparing distinct definitions. ${ }^{97}$

No right is absolute under the NZBORA. ${ }^{98}$ Section 5 states that the rights and freedoms contained in the NZBORA are "subject only to such reasonable limits prescribed by law as can be demonstrably justified in a free and democratic society". When assessing whether there is infringement of rights in its decision making, the Office and Board should consider whether their decision is consistent with the right as reasonably limited under s 5, rather than the absolute right. ${ }^{99}$ It has been suggested the overly technical test for reasonable limitation adopted in $R v$ Hansen should be dropped in favour of a less complex balancing of values underlying the relevant right and relevant statute. ${ }^{100}$ This kind of approach to s 5 was well demonstrated in Television New Zealand $v$ West. ${ }^{101}$ The High Court held that a s 5 analysis is necessary in order to justify any restriction of rights. ${ }^{102}$ However, the required analysis does not need to be overly burdensome as long as it is transparent. ${ }^{103}$ In terms of the FVPC Act, this would involve a balancing of the values behind the right to freedom of expression with the values behind the statute itself, as they relate to the specific publication.

\section{B Freedom of Expression}

An understanding of the purpose of the right to freedom of expression is vital in order to determine whether a restriction is justified. The NZBORA states that "[e]veryone has the right to freedom of expression, including the freedom to seek, receive, and impart information and opinions". ${ }^{104}$ This right is "as wide as human thought and imagination". ${ }^{105}$

Freedom of expression is widely accepted as being deserving of protection for a number of reasons. The most common justifications are that it provides society with a way to search for the truth,

to the Broadcasting Standards Authority, but the reasoning is useful when considering administrative bodies in general, including the Office and the Board.

97 At 302-303

98 Section 3

$99 R v$ Hansen, above $\mathrm{n}$ 95, at [88] and [91] per Tipping J; Meredith Webb "Applying the Bill of Rights in the New Zealand Context" (2007) 13 AULR 217 at 218; and Geiringer and Price, above n 96, at 303.

100 Geiringer and Price, above n 96, at 316. The Board has also frequently expressed their difficulty in applying the similarly technical Moonen test: see for example "Grand Theft Auto IV (Unedited Version)", above n 48, at [98].

101 Television New Zealand Ltd $v$ West [2011] 3 NZLR 825 (HC).

102 At [105].

103 Television New Zealand Ltd v West, above n 101, at [98].

104 Section 14.

105 Moonen v Film and Literature Board of Review, above n 52, at [15]. 
to participate fully in a functioning democracy, and to be a healthy and functioning individual. ${ }^{106}$ An alternative conception of the right to freedom of expression asserts that allowing circulation of information encourages development of characteristics which are desirable for a fully functioning society. ${ }^{107}$ Excessive censorship actively discourages discourse, but allowing freedom of expression encourages people to engage with opposing viewpoints, check and challenge facts and authorities, and compromise. ${ }^{108}$ A person who readily engages in these practices becomes more inquisitive and creative, and is able to take initiative, question authority and adapt to change. ${ }^{109}$ Freedom of expression fosters the development of traits which are beneficial to wider society and can create informal checks and balances on false or harmful information, rather than requiring the intervention of the law. ${ }^{110}$

This social value must be balanced with the purposes of the FVPC Act when a publication is being classified, in order to properly discuss the NZBORA.

\section{Implications}

Currently, the Office makes regular references to the NZBORA in its decisions, while the Board does so less regularly. Both the Office and the Board should strive to apply the NZBORA more consistently, particularly s 5 . Balancing the merit of the publication and the purpose of the FVPC Act could also assist in a more thorough and consistent discussion of seriousness of harm.

When making decisions, the Office and Board should first consider whether the form of expression that is taking place is a significant one. If the publication aligns with the values behind the right to freedom of expression, such as communicating valuable social or political commentary or promoting discourse in the wider public, it will be less appropriate to restrict. Next, the purpose of the legislation should be assessed. While the FVPC Act in general purports to prevent harm to the public good by restricting access to harmful publications, ss 3, 3A, and 3B all have slightly different purposes and could justify a restriction in their own right. Section 3 focuses on general likelihood of injury to the public, while s 3A refers to serious harm to young persons. The NZBORA analysis should be directed at the sections individually so that each purpose can be fully discussed, but also to ensure

106 Andrew Butler and Petra Butler The New Zealand Bill of Rights Act: A Commentary (2nd ed, LexisNexis, Wellington, 2015) at 523; and Geiringer and Price, above n 96, at 320.

107 Vincent Blasi "Free Speech and Good Character: From Milton to Brandeis to the Present" in Lee C Bollinger and Geoffrey R Stone (eds) Eternally Vigilant: Free Speech in the Modern Era (University of Chicago Press, Chicago, 2002) 61 at 62.

108 At 67 and 85-88.

109 At $83-84$.

110 At 94. 
that they are not confused. This would prevent the current situation where offensive language is often discussed along with s 3 material under a general injury test.

Finally, the merits of the publication should be weighed against the purpose of $\mathrm{s} 3 \mathrm{~A}$ to determine whether a restriction is justified. The process is based on judgement rather than strict legality: if the publication has significant merit, there will have to be a significant level of harm caused to justify a restriction. ${ }^{111}$ If the publication's language is likely to cause serious harm, there must be considerable merit to avoid restriction. This would particularly assist in determining what constitutes "serious harm" for the purposes of the legislation. Harm labelled "serious" in the past, such as using offensive language in inappropriate settings, is far less likely to be considered serious when balanced with the importance of protecting significant speech.

For example, the film Black Mass tells the true story of Jimmy "Whitey" Bulger, a notorious gangster in South Boston in the 1970s and 80s. ${ }^{12}$ He slowly rises in the criminal world by abusing his role as an FBI informant. The film ultimately ends with the gangsters and corrupt officers alike being brought to justice. While violent, it discusses important societal themes of loyalty and corruption, while advocating a "crime doesn't pay" message.

Originally rated R18 by the Office, the Board changed the classification to R16 in $2015 .{ }^{113}$ However, the reasoning behind the restriction was based almost purely on the offensive language used within the film. ${ }^{114}$ It stated that s 3A plainly applied, therefore limiting the right to freedom of expression. ${ }^{115}$ However, upon a more measured approach it seems unlikely that a classification of the film under s 3A alone could justify such a decision. The majority of swearing in the film is conversational - which one might expect from members of the criminal underworld - or used to express intense emotions or pain. Very occasionally swearing is used to threaten and on two occasions it is used in conjunction with violence, which is more likely to meet the "highly offensive" threshold. The use of the language creates a potential harm that younger viewers may emulate it in a way which could cause social isolation, and potentially lead to increased violence. However, the publication is quite a valuable form of communication as it encourages discussion and consideration of important topics. In most cases the swearing is realistic, and highly offensive uses are relatively few. It seems unjustified to restrict the film to those aged 16 years or older when the less serious harm of offensive language is contrasted with the social utility of the film.

111 Geiringer and Price, above n 96, at 335.

112 Black Mass (2015).

113 "Black Mass", above n 50.

114 At [10].

115 At [12]. 
If the Board took into account other aspects of the film, especially its almost excessive use of violence, it could probably have justified a higher restriction. Perhaps this demonstrates the need for a more rounded approach to the legislation as a whole, as well as s $3 \mathrm{~A}$. It also shows that while a more consistent application of $\mathrm{s} 3 \mathrm{~A}$ is desirable, there are very few cases where a classification would turn on that section alone, and even fewer where that classification would result in a restriction.

Overall, it appears that the Office and Board should be very cautious before deciding that there is a serious harm created by the use of highly offensive language in a publication. They should not be influenced by the presence of other apparently harmful considerations under s 3 , such as violence or nudity. Instead, they should focus on the harm that is caused by the language itself, with the importance of freedom of expression assisting in determining when the harm is severe enough to allow restriction. The Board has observed the threshold of harm set by s $3 \mathrm{~A}$ as a high one, and the relevant research supports that finding. ${ }^{116}$

\section{CONCLUSION}

Section 3A of the FVPC Act has been applied constantly, but not consistently, since it was introduced in 2005. Both the Office and the Board have trouble identifying whether words can be considered to be highly offensive, and what harm is serious enough to warrant a restriction. Any application of the NZBORA is usually done in a bulk conclusion, creating confusion as to which part of the legislation has justified a restriction and neglecting to take into account the purpose of s 3A.

The Office and Board could both benefit from the research surrounding offensive language and the harm it can cause. But a separate consideration of the NZBORA, and a measuring of the harm against the relative importance of freedom of expression, would provide a more consistent way for both the Office and the Board to identify which harm is actually serious enough to result in a restriction. This could result in fewer restrictions under s $3 \mathrm{~A}$, and more clarity when it does become relevant. The majority of decisions may continue to be made in relation to the main gateway of sex, horror, crime, cruelty and violence, but more certainty in the law surrounding s $3 \mathrm{~A}$ will lead to better understanding both for those enforcing the legislation and those seeking to abide by it.

116 "Into the River", above n 68. 